\title{
Modeling the Effects of Tool Probe Geometries and Process Parameters on Friction Stirred Aluminium Welds
}

\author{
H. K. Mohanty ${ }^{1}$, D.Venkateswarlu ${ }^{1}$, M. M. Mahapatra ${ }^{1, *}$, Pradeep Kumar $^{1}$, N. R. Mandal ${ }^{2}$ \\ ${ }^{1}$ Mechanical and Industrial Engineering Department, IIT Roorkee, Roorkee, 247 667, India \\ ${ }^{2}$ Department of Ocean Engineering \& Naval Architecture, IIT Kharagpur, Kharagpur, 721 302, India
}

\begin{abstract}
The weld properties of friction stir welding remains as an area of interest with respect to the effect of tool geometry and process parameters. In the present investigation effort has been made to understand the effect of important welding parameters such as tool rotational speed, traverse speed and probe geometries on various mechanical properties of AA1100 aluminium alloys. Ultimate tensile strength, percentage of elongation and hardness were determined experimentally for this purpose. Analysis of variance (ANOVA) was used to observe the main effect of above mentioned parameters on mechanical properties. A regression relationships were developed to predict each output. The experimental and predicted values from the mathematical model were in close agreement.
\end{abstract}

Keywords Friction Stir Welding, Regression Analysis, Tool Designs

\section{Introduction}

Friction stir welding (FSW) is a solid-state joining process which welds the materials whose characteristics almost remain unchanged as far as possible. Difficult to weld and weldable alloys can be joined by this process without melting and recasting[1]. Welding defects such as porosity and hot cracking are not an issue in FSW and joints with low residual stresses, improved dimensional stability, good mechanical properties and high surface finish are produced. During FSW processing, a non consumable tool attached with a desired designed pin is inserted to butting edge of the plates to be joined. Tool shoulder touches the plate surface with vertical pressure. Under this condition the tool is rotated and traversed along bond line. Frictional heat is generated, material gets softened locally and plastic deformation of the work piece occurs. Tool rotation and translation expedite material flow from front to back of the pin and welded joint is produced[2]. It is essentially a thermo-mechanical process during which the temperature of the material is taken to a range where it can be plastically deformed to yield a fine-grained structure.

The heat input to the material depends on the FSW tool geometry and parameters. Many studies conducted on FSW of aluminium alloys show that a number of process parameters can affect the welding conditions and the weld properties[3]. In several studies the influence of stirrer design on the welding process was also investigated. For this

* Corresponding author:

manasmohan2@gmail.com (M .M. Mahapatra)

Published online at http://journal.sapub.org/jmea

Copyright (C) 2012 Scientific \& Academic Publishing. All Rights Reserved purpose, five different stirrers, one of them square cross-sectioned and the rest were cylindrical with different screw pitched were used to carry out welding process[4]. Microscopic examination of the weld zone and the tension test results showed that the best bonding was obtained with $0.85 \mathrm{~mm}$ screw pitched stirrer. The quality of a FSW joint is also affected by tool geometry: in particular the diameter and the shape of the pin as well as the shoulder surface. They strongly influence both metal flow and heat generation[5].Moreover, both rotation speed and feed rate have to be appropriately chosen in order to obtain effective joints[6]. The effects of welding parameters, tool geometry and position of the pin axes were investigated by researchers [7-10] in to obtain high quality welds. A lot of efforts have been undertaken towards understanding the effect of process parameters on the material flow behavior, micr structure formation and hence mechanical properties of friction stir welded joints. Finding the most effective parameters of friction stir welds, as well as realizing their influence on the weld properties is still have been major topics for researchers. The influence of some of these important parameters such as the rotational speed and the traverse speed on weld properties were investigated by Elangovan and Balasubramanian[11]. Blignault et al. considered optimization procedures for friction stir welding (FSW) in 5083-H321 aluminum alloy, via control of weld process parameters and tool design modifications[12]. They used "force footprint" (FF) diagram in providing a real-time graphical user interface (GUI) for process optimization of FSW. Desirability profile charts were presented, which showed the influence of seven key combinations of weld process variables on tensile strength[12]. The friction stir welding process and tool parameters were optimized by Rajakumar and Balasubrama- 
nian using multi-response optimization technique to obtain the maximum strength and minimum corrosion rate of FS welded AA1100 aluminium alloy[14].They observed that rotational speed is more sensitive than other parameters followed by axial force, welding speed, shoulder diameter, pin diameter, and tool material hardness[14]. Vijayan et al. reported the optimization of FSW process parameters for AA5083 aluminum alloy with multiple responses based on orthogonal array with gray relational analysis[17]. The authors found the optimum levels of the process parameters to attain maximum tensile strength and minimum power consumption[17]. In spite of these achievements the combined effect of probe geometry and processes parameter on mechanical properties on friction stir welded AA1100 aluminium alloy has not yet been systematically classified. In this present investigation an attempt has been made to find out the key parameters (probe geometry, process parameter) that affect the tensile strength, percentage of elongation, nugget grain size and nugget hardness most, and also to develop a mathematical model to establish the correlation between factors and responses such as tensile strength, percentage of elongation and nugget hardness of friction stir welded AA1100 aluminium alloy joint by using design of experiment, analysis of variance and regression analysis.

\section{Experimental Details}

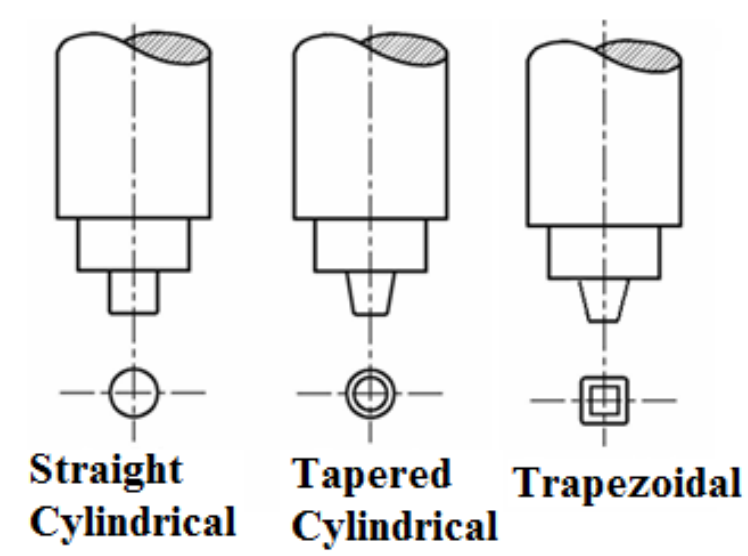

Figure 1. The schematic of tool geometries

The experimental campaign in this study was conducted using three different types of tool probe such as straight cylindrical, tapered cylindrical and trapezoidal shape. It is to be noted that tools with different probe geometries and their effects on friction stir weld were studied earlier by the author to select the above described tools which produces better welds[18]. SS310 alloy was used to fabricate the tools. The chemical composition and physical properties of the SS310 tool material are given in Tables 1 and 2 respectively. All the tools were having same probe tip diameter of 5 millimeter size. The schematic of tool geometries are shown in Figure 1. Commercial grade AA1100 aluminium alloy of $6 \mathrm{~mm}$ thickness plate was used as base metal to carry out the ex- periment in a vertical milling machine. The chemical composition of the alloy are given in the Table 3. Several specimen of $300 \mathrm{~mm}$ long and $150 \mathrm{~mm}$ wide were cut out of base metal by using a power hacksaw. The edges of the specimen were machined to obtain a perfect square butt joint configuration. The test pieces were clamped in machine bed by using suitable fixture. Tool was mounted in a vertical arbor with a suitable collate[18]. The vertical tool head can be moved along the vertical guide way ( $Z$ axis) the horizontal bed can be moved along $\mathrm{X}$ and $\mathrm{Y}$ axis.

\subsection{Investigation Plan}

This investigation was planned to be carried out in following steps

(i) Identifying the important process parameter and finding the range of process parameter such as tool rotational speed and welding speed .

(ii) Developing of design matrix and conducting the experiments as per the design matrix.

(iii) Collection of experimental data.

(iv)Regression analysis (Developing mathematical model and checking the adequacy)

(v) Conformity test.

(vi)Analysis of the results (Effect of control factors on responses).

The important processes parameters (rotational speed, welding speed) and tool probe geometry were identified based on series of trials and author's earlier study[18]. Tools with different probe geometries, trial experiment runs were conducted to select the range of feasible process parameters such a way that the friction stirred welded joint should be free from any visible external defect. The selected process parameters with their levels are given in Table 4 . The experiment was based on three factors with three levels of full factorial experimental design. The developed design matrix is shown in Table 5. As prescribed in the experimental design matrix twenty seven joints were carried out using previously described tools having three different probe geometry by varying three levels of process parameter, namely tool rotational speed and welding speed as given in the Table 4. It is to be further noted that the experiments were conducted with a constant axial load of $3.5 \mathrm{KN}$.

Table 1. Composition of FSW tool material by percentage

\begin{tabular}{|c|c|c|c|c|c|c|c|}
\hline $\mathrm{Fe}$ & $\mathrm{C}$ & $\mathrm{Cr}$ & $\mathrm{Mn}$ & $\mathrm{Ni}$ & $\mathrm{P}$ & $\mathrm{S}$ & $\mathrm{Si}$ \\
\hline $48-53$ & 0.25 & $24-26$ & 2 & $19-22$ & 0.045 & 0.03 & 1.5 \\
\hline
\end{tabular}

Table 2. FSW tool material physical properties

\begin{tabular}{|c|c|}
\hline Hardness, Brinell & 160 \\
\hline Tensile strength, ultimate (MPa) & 655 \\
\hline Tensile strength, yield (MPa) & 275 \\
\hline
\end{tabular}


Table 3. Composition of $\mathrm{Al}$ alloy by percentage

\begin{tabular}{|c|c|c|c|c|c|c|c|c|c|}
\hline $\mathrm{Al}$ & $\mathrm{Si}$ & $\mathrm{Cu}$ & $\mathrm{Cr}$ & $\mathrm{Fe}$ & $\mathrm{Mn}$ & $\mathrm{Mg}$ & $\mathrm{Zn}$ & $\mathrm{Ni}$ & $\mathrm{As}$ \\
\hline 99.1 & .4 & .01 & .001 & .4 & .007 & .0011 & .00 & .0021 & .002 \\
\hline
\end{tabular}

Table 4. FSW parameters and their levels

\begin{tabular}{|c|c|c|c|c|}
\hline Parameter & Notation & Level (-1) & Level $(0)$ & Level $(+1)$ \\
\hline $\begin{array}{c}\text { Welding speed } \\
\text { (mm/min) }\end{array}$ & WS & 80 & 160 & 212 \\
\hline $\begin{array}{c}\text { Rotational } \\
\text { speed (rev/min) }\end{array}$ & RS & 710 & 1000 & 1400 \\
\hline $\begin{array}{c}\text { Tool probe } \\
\text { geometry }\end{array}$ & TPG & straight & Tapered & Trapezoidal \\
\hline
\end{tabular}

Tensile tests were performed to determine the tensile properties of the weld material such as tensile strength and percentage of elongation. Tensile specimen from each welded plate were sliced perpendicular to the welding direction and prepared as per the ASTM E8M-04 standard. The ultimate tensile strength and percentage of elongation of FS welded joint were evaluated in a servo tensile test machine at constant cross head displacement $10 \mathrm{~mm} / \mathrm{min}$. Some of the in-house designed and manufactures tools and FS welded plate are shown in Figure 2. Metallographic examination on the transverse cross sections was carried out to study the nugget structure. The samples were thoroughly polished and then etched with Keller's reagent to study the microstructure and the hardness was determined by means of an indenter entering the material to be tested with a specific load and dwell time. After removing the indenter, the produced imprint was measured and the "hardness number" calculated. The Vickers indenter is a four sided pyramid with square base, with an apex angle between opposite sides of $\alpha=136 \mathrm{deg}\left( \pm 15^{\prime}\right)$. The hardness number (HV) was calculated by dividing the load (indentation force) by the surface of the imprint. Hardness measurements were taken on the cross sections perpendicular to the welding direction. In the present investigation, the indentation load was kept at $100 \mathrm{gf}$.The measured output responses such as tensile strength, percentage of elongation, and nugget hardness are presented in Table 5.The prepared tensile specimen after fracture and bend test specimens are shown in Figure 3.

a

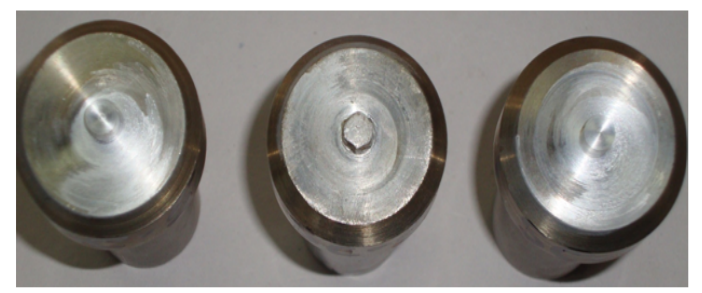

b

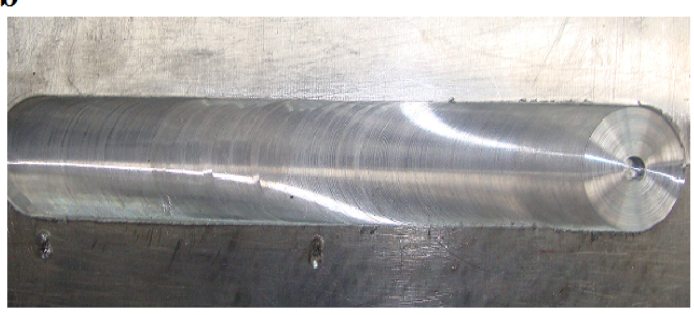

Figure 2. (a) Three types of tools and, (b) FS butt welds produced

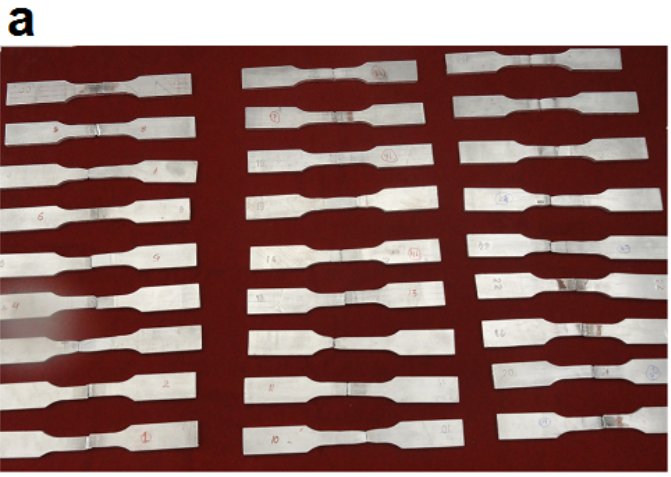

b

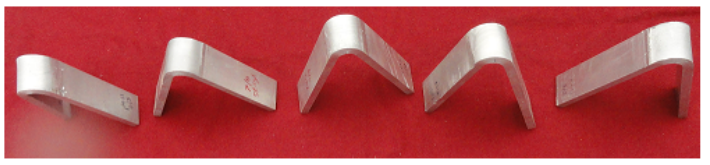

Figure 3. (a) Tested tensile sample, (b) bend test samples

\section{Response Surface Modeling}

The process window created using the DOE approach resulted 27 experimental inputs as shown in Table 5. These experiments were conducted and three outputs such as weld strength, \% elongation and nugget hardness were used for the response surface regression modeling using MINI$\mathrm{TAB}[13]$.

Table 5. Experimental data

\begin{tabular}{|c|c|c|c|c|c|c|}
\hline $\begin{array}{c}\text { Sl. } \\
\text { No }\end{array}$ & $\begin{array}{c}\text { Tool } \\
\text { type }\end{array}$ & $\begin{array}{c}\text { Rotation } \\
\text { speed }\end{array}$ & $\begin{array}{c}\text { Weld } \\
\text { speed }\end{array}$ & $\begin{array}{c}\text { Tensile } \\
\text { strength }\end{array}$ & $\begin{array}{c}\text { Nugget } \\
\text { hardness }\end{array}$ & $\begin{array}{c}\% \\
\text { Elong } \\
\text {-ation }\end{array}$ \\
\hline 1 & -1 & -1 & -1 & 77.12 & 55 & 6.5 \\
\hline 2 & -1 & -1 & 0 & 63.45 & 53 & 5.6 \\
\hline 3 & -1 & -1 & +1 & 56.44 & 49 & 4.1 \\
\hline 4 & -1 & 0 & -1 & 85.22 & 60 & 7.2 \\
\hline 5 & -1 & 0 & 0 & 82.11 & 62 & 8.7 \\
\hline 6 & -1 & 0 & +1 & 64.23 & 51 & 5.9 \\
\hline 7 & -1 & +1 & -1 & 101.9 & 64 & 10.9 \\
\hline 8 & -1 & +1 & 0 & 107 & 67 & 11 \\
\hline 9 & -1 & +1 & +1 & 83.56 & 57 & 9.4 \\
\hline 10 & 0 & -1 & -1 & 76.34 & 48 & 6.2 \\
\hline 11 & 0 & -1 & 0 & 80.99 & 57 & 6.5 \\
\hline 12 & 0 & -1 & +1 & 69.12 & 46 & 4.7 \\
\hline 13 & 0 & 0 & -1 & 77.11 & 57 & 6.8 \\
\hline 14 & 0 & 0 & 0 & 90 & 61 & 8.3 \\
\hline 15 & 0 & 0 & +1 & 75.31 & 49 & 5.4 \\
\hline 16 & 0 & +1 & -1 & 83.15 & 55 & 7.4 \\
\hline 17 & 0 & +1 & 0 & 85 & 59 & 9.3 \\
\hline 18 & 0 & +1 & +1 & 76.19 & 50 & 7.5 \\
\hline 19 & +1 & -1 & -1 & 70.72 & 49 & 5.9 \\
\hline 20 & +1 & -1 & 0 & 76.22 & 53 & 5.6 \\
\hline 21 & +1 & -1 & +1 & 64.22 & 46 & 4.6 \\
\hline 22 & +1 & 0 & -1 & 74.88 & 52 & 5.8 \\
\hline 23 & +1 & 0 & 0 & 86.11 & 61 & 6.4 \\
\hline 24 & +1 & 0 & +1 & 63.33 & 45 & 4.1 \\
\hline 25 & +1 & +1 & -1 & 67.17 & 49 & 5.2 \\
\hline 26 & +1 & +1 & 0 & 71.22 & 55 & 6.2 \\
\hline 27 & +1 & +1 & +1 & 65.22 & 43 & 7 \\
\hline & & & & & & \\
\hline
\end{tabular}




\subsection{Regression Analysis}

The response (Y) such as tensile strength (TS), percentage of elongation (EL) and weld nugget hardness (WHN) of the joints are functions of tool probe geometry(TPG), rotational speed (RS) and welding speed (WS) and it can be expressed as

$$
\mathrm{Y}=\mathrm{f}(\mathrm{TPG}, \mathrm{RS}, \mathrm{WS})
$$

For the above three factors, the developed mathematical model equations $(2,3$ and 4$)$ are given below.

$\mathrm{TS}=(85.71)+(-4.552 * \mathrm{TPG})+(5.877 * \mathrm{RS})+(-5.33 * \mathrm{WS})+(-$ $3.683 * \mathrm{TPG} * \mathrm{TPG})+(-1.198 * \mathrm{RS} * \mathrm{RS})+(-8.498 * \mathrm{WS} * \mathrm{WS})+($ $-8.583 * \mathrm{TPG} * \mathrm{RS})+(3.334 * \mathrm{TPG} * \mathrm{WS})+(0.596 * \mathrm{RS} * \mathrm{WS})(2)$

$$
\begin{gathered}
\mathrm{EL}=(7.426)+(-1.028 * \mathrm{TPG})+(1.344 * \mathrm{RS}) \\
+(-0.511 * \mathrm{WS})+(-0.228 * \mathrm{TPG} * \mathrm{TPG})+ \\
(0.356 * \mathrm{RS} * \mathrm{RS})+(-1.144 * \mathrm{WS} \mathrm{WS})+ \\
(-1.067 * \mathrm{TPG} \mathrm{RS})+(0.333 * \mathrm{TPG} * \mathrm{WS})+ \\
(0.467 * \mathrm{RS} * \mathrm{WS}) \\
\mathrm{WNH}=(59.926)+(-3.611 * \mathrm{TPG})+(2.389 * \mathrm{RS})+ \\
(-2.944 * \mathrm{WS})+(0.389 * \mathrm{TPG} \text { TPG })+ \\
(-2.278 * \mathrm{RS} * \mathrm{RS})+(-7.278 * \mathrm{WS} * \mathrm{WS})+ \\
(-2.667 * \mathrm{TPG} \mathrm{RS})+(0.500 * \mathrm{TPG} \text { WS }) \\
+(-0.583 * \mathrm{RS} * \mathrm{WS})
\end{gathered}
$$

The adequacy of the models so developed was then tested by using the analysis of variance technique (ANOVA). The analysis of variance (ANOVA) for tensile strength, percentage of elongation and weld nugget hardness are shown in Table 6,7 and 8 respectively. For the models developed, it was seen that the calculated $\mathrm{R}^{2}$ values and and adjusted $\mathrm{R}^{2}$ values are above $80 \%$.These values indicate that the regression models are quite adequate.

Table 6. ANOVA table of weld strength

\begin{tabular}{|c|c|c|c|c|c|c|}
\hline \multicolumn{7}{|c|}{ Analysis of Variance for Tensile strength: (Response Surface Regression: } \\
\hline Source & $\begin{array}{c}\text { D } \\
\text { F }\end{array}$ & Seq SS & Adj SS & Adj MS & F & P \\
\hline $\begin{array}{c}\text { Regres- } \\
\text { sion }\end{array}$ & 9 & 3115.81 & 3115.81 & 346.20 & 14.25 & $<0.000$ \\
\hline Linear & 3 & 1376.21 & 1599.08 & 533.02 & 21.94 & $<0.000$ \\
\hline Square & 3 & 655.90 & 655.90 & 218.63 & 9.00 & $<0.001$ \\
\hline Interaction & 3 & 1083.70 & 1083.70 & 361.23 & 14.87 & $<0.000$ \\
\hline $\begin{array}{c}\text { Residual } \\
\text { Error }\end{array}$ & 17 & 413.05 & 413.05 & 24.29 & & \\
\hline Total & 26 & 3528.86 & & & & \\
\hline
\end{tabular}

Table 7. ANOVA table of weld strength \% Elongation

\begin{tabular}{|c|c|c|c|c|c|c|}
\hline \multicolumn{7}{|c|}{ Analysis of Variance for \% Elongation: (Response Surface Regression:R-Sq } \\
\hline \multicolumn{7}{|c|}{$92.9 \%$, R-Sq(adj) $89.2 \%$. } \\
\hline Source & DF & Seq SS & Adj SS & Adj MS & F & P \\
\hline $\begin{array}{c}\text { Regres- } \\
\text { sion }\end{array}$ & 9 & 83.57 & 83.57 & 9.28 & 24.75 & $<0.001$ \\
\hline Linear & 3 & 55.86 & 57.03 & 19.01 & 50.68 & $<0.001$ \\
\hline Square & 3 & 9.75 & 9.75 & 3.25 & 8.67 & $<0.001$ \\
\hline $\begin{array}{c}\text { Interac- } \\
\text { tion }\end{array}$ & 3 & 17.95 & 17.95 & 5.98 & 15.96 & $<0.000$ \\
\hline $\begin{array}{c}\text { Residual } \\
\text { Error }\end{array}$ & 17 & 6.37 & 6.37 & 0.37 & & \\
\hline Total & 26 & 89.94 & & & & \\
\hline
\end{tabular}

Table 8. ANOVA table of weld nugget hardness

\begin{tabular}{|c|c|c|c|c|c|c|}
\hline \multicolumn{7}{|c|}{ Analysis of Variance for nugget hardness (HV) : (Response Surface Regres- } \\
\hline Sion: $\mathrm{R}-\mathrm{Sq}=94.0 \%, \mathrm{R}-\mathrm{Sq}(\mathrm{adj})=90.8 \%$. \\
\hline Source & $\mathrm{DF}$ & Seq SS & $\begin{array}{c}\text { Adj } \\
\text { SS }\end{array}$ & $\begin{array}{c}\text { Adj } \\
\text { MS }\end{array}$ & $\mathrm{F}$ & $\mathrm{P}$ \\
\hline Regression & 9 & 960.66 & 960.66 & 106.74 & 29.66 & $<0.000$ \\
\hline Linear & 3 & 439.04 & 525.74 & 175.24 & 48.69 & $<0.000$ \\
\hline Square & 3 & 438.96 & 438.96 & 146.32 & 40.65 & $<0.000$ \\
\hline Interaction & 3 & 82.66 & 82.66 & 27.55 & 7.66 & $<0.002$ \\
\hline Residual & 17 & 61.19 & 61.18 & 3.59 & & \\
Error & 26 & 1021.85 & & & & \\
\hline Total & 26 & & & & \\
\hline
\end{tabular}

\subsection{Conformity test}

Experiments were conducted to verify the regression equations( 2),(3)and (4).Six joints were fabricated, two out of each tool probe using different values of rotational speed and welding speed other than what were used in the design matrix (Table 5). The details of test result are presented in Table 9, which indicate that the experimental and predicted values are in good agreement.

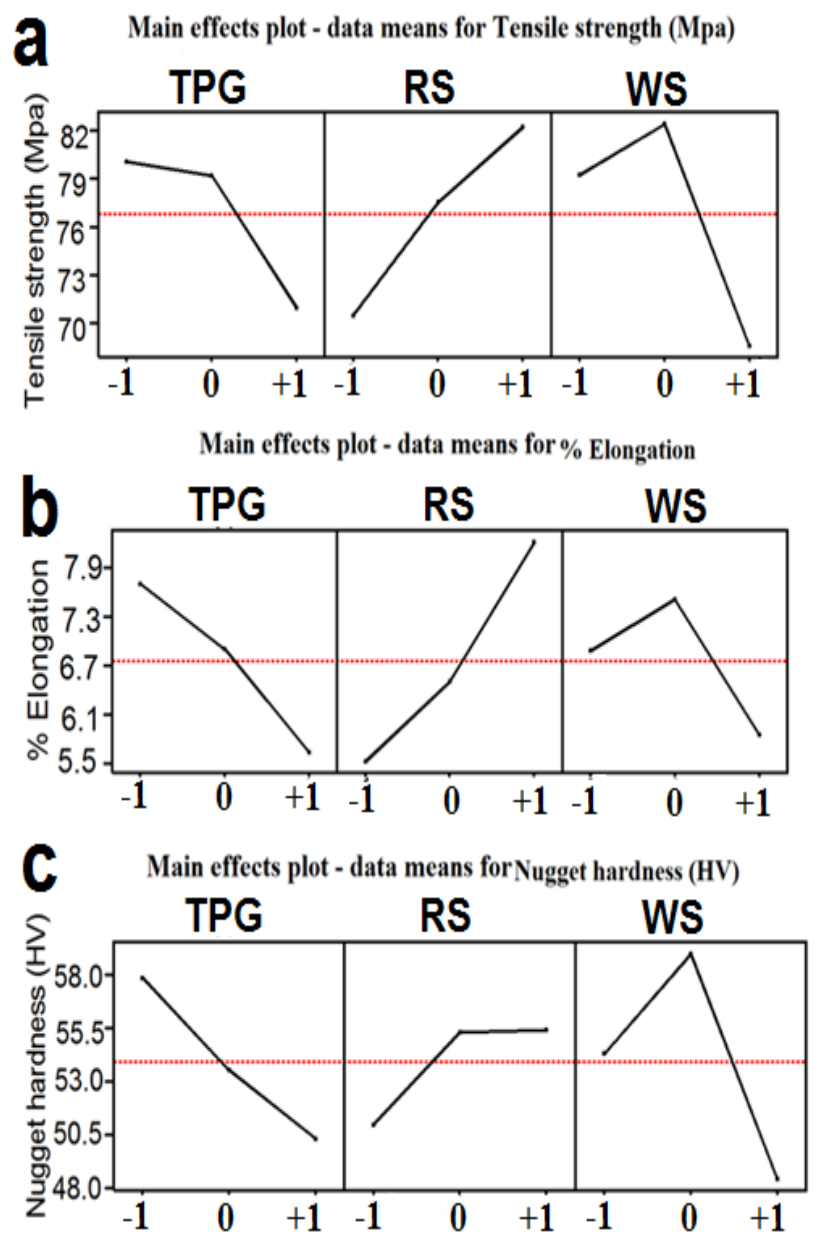

Figure 4. Main effect plots for (a) Ultimate tensile strength; (b) \% Elongation; (c) Nugget hardness 
Table 9. Conformity test results

\begin{tabular}{|c|c|c|c|c|c|c|c|c|c|c|c|c|}
\hline & \multicolumn{2}{|c|}{ Test case input variables } & \multicolumn{9}{|c|}{ Percentage error from the model prediction } \\
\hline $\begin{array}{c}\text { Sl. } \\
\text { No }\end{array}$ & $\begin{array}{c}\text { Tool } \\
\text { type }\end{array}$ & $\begin{array}{c}\text { Rotation } \\
\text { speed } \\
(\mathrm{rpm})\end{array}$ & $\begin{array}{c}\text { Weld speed } \\
(\mathrm{mm} / \mathrm{min})\end{array}$ & $\begin{array}{c}\text { Tensile } \\
\text { strength } \\
(\mathrm{MPa})\end{array}$ & $\begin{array}{c}\text { Tensile strength } \\
\text { predicted } \\
(\mathrm{MPa})\end{array}$ & $\begin{array}{c}\% \\
\text { Error }\end{array}$ & $\begin{array}{c}\% \text { elon- } \\
\text { gation }\end{array}$ & $\begin{array}{c}\% \text { elon- } \\
\text { gation } \\
\text { predicted }\end{array}$ & $\begin{array}{c}\% \\
\text { Error }\end{array}$ & $\begin{array}{c}\text { Nugget } \\
\text { hardness } \\
(\mathrm{HV})\end{array}$ & $\begin{array}{c}\text { Nugget } \\
\text { hardness (HV) } \\
\text { predicted }\end{array}$ & $\begin{array}{c}\text { \% } \\
\text { Error }\end{array}$ \\
\hline 1 & 1 & 625 & 75 & 66 & 66.93 & -1.40 & 4.3 & 4.02 & 6.96 & 47 & 49.36 & -4.92 \\
\hline 2 & 1 & 1120 & 165 & 87.33 & 89.23 & -2.13 & 6.2 & 6.42 & -3.43 & 62 & 65.01 & -4.63 \\
\hline 4 & 2 & 625 & 75 & 71 & 72.59 & -2.20 & 4.5 & 4.72 & -4.73 & 46 & 47.31 & -2.78 \\
\hline 5 & 2 & 1120 & 165 & 81.22 & 86.97 & -6.60 & 6 & 5.50 & 8.89 & 61 & 60.21 & 1.31 \\
\hline 7 & 3 & 625 & 75 & 66 & 70.90 & -6.91 & 4.5 & 4.41 & 1.83 & 48 & 46.37 & 3.49 \\
\hline 8 & 3 & 1120 & 165 & 80 & 77.36 & 3.40 & 5 & 3.59 & 38.9 & 55 & 56.51 & -2.68 \\
\hline
\end{tabular}

\subsection{Analysis of the results}

The main effect plots for the control factors and the responses were also plotted and analyzed. Figure 4 (a), (b) and (c) indicate the main effects plot for tensile strength, percentage of elongation and nugget hardness. The following observations can be made from the above Figure 4. (i) Welding speed has got significant effect on tensile strength followed by rotational speed and probe geometry. (ii) Tensile strength increases with increasing welding speed up to certain point and there after it decreases. Similar trends were also observed for percentage of elongation and nugget hardness. Straight cylindrical probe produces maximum weld strength, percentage of elongation and nugget hardness. As the heat generation in FSW process is thermo mechanical[19], therefore the mechanical action due to processes parameter and probe geometry significantly affects the mechanical and metallurgical properties of weld. Heat generated due to friction is mainly due to rotation of tool and the welding speed is responsible for the quantity of heat supplied to the base material to be welded subsequently rate of cooling[19].

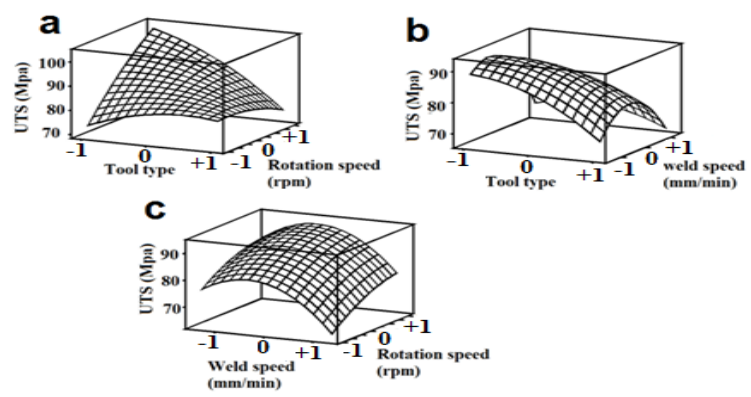

Figure 5. Surface response plots for ultimate tensile strength

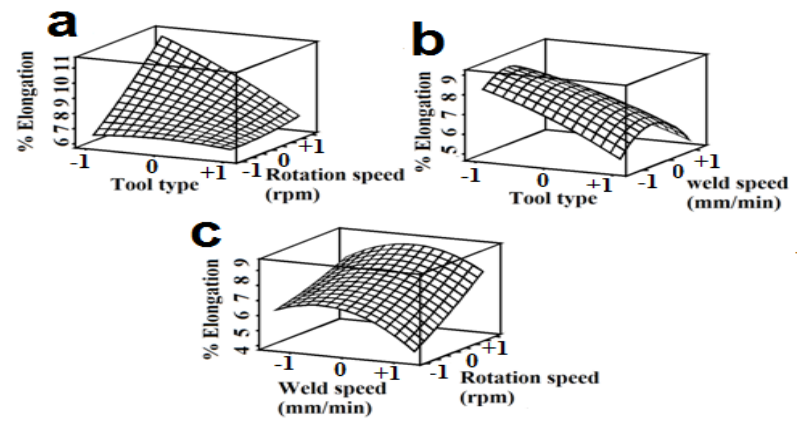

Figure 6. Surface response plots for \% Elongation of welds during tensile testing

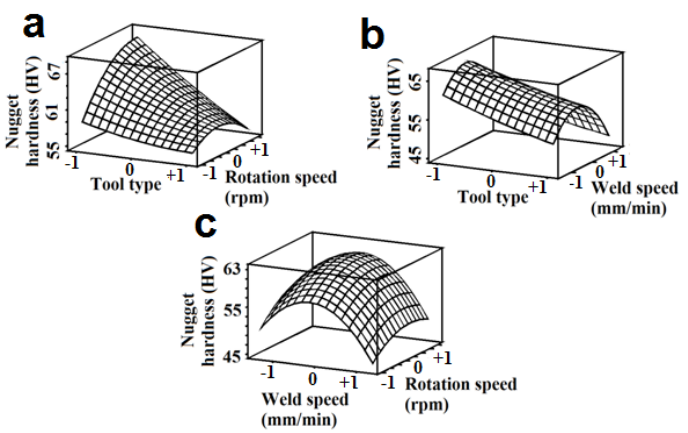

Figure 7. Surface response plots for nugget hardness of welds

The surface response plots for ultimate tensile strength , \% elongation and nugget hardness are presented in Figures 5-7. From the surface plots and the main effect plot it is observed that the tensile strength of the joints decreased beyond the welding speed of $160 \mathrm{~mm} / \mathrm{min}$ (level 2). Similar trends is also observed for percentage elongation and nugget hardness. Welding speed of $212 \mathrm{~mm} / \mathrm{min}$ produced joints with lower weld strength. From the regression analysis it is observed that the rotational speed of tool has got significant effect on percentage of elongation followed by probe geometry and welding speed. Percentage of elongation increases with increasing rotational speed. Further it can be stated that the welding speed has got significant effect on nugget hardness followed by probe geometry and rotational speed. Result from the above observation; it can be presumed that tool probe geometry and process parameters play a major role on the mechanical properties of FS welded AA1100 aluminium alloys. Maximum rotational speed and welding speed increase heat input and cooling rate causes turbulent material flow. Moreover short interaction time between tool and work piece deteriorates weld quality. Similarly lowest tool rotation and welding speed result low heat generation and grain growth become sluggish, therefore weld quality deteriorate due to insufficient material flow. As a whole neither low heat input nor high heat input is preferred to achieve superior weld quality as it evident from Figure 5. On observation 1and 3 it is clear that traverse speed has got significant effect on tensile strength. It is mainly due to plastic deformation and lower heat input. Similarly it can be stated from observation 2 that the higher rotational speed generates more heat thus improve ductility of weld. Tool probe geometry is responsible for the grain size of nugget zone. The primary function of tool probe is to 
stir the plastisized material and play a major role during material flow in FSW process. Based on Schmidt et al. analytical model probe side surface contributes at about $11 \%$ of total heat generation during the process[20]. Therefore probe geometry plays a crucial role in both heat generation and material flow in the FSP region. Trapezoidal probe has got sharp edge corner which is responsible for excessive heat generation as compared to others. Therefore trapezoidal probe produces weld of poor strength as compare to others.

\section{Conclusions}

The following conclusion can be arrived from the present investigation.

1. The tensile strength, percentage of elongation and nugget hardness increase with increasing welding speed up to a certain range thereafter decrease.

2. Neither low heat input nor high heat input is preferred to achieve superior weld quality.

3. Ductility of FSW joint very much depends upon the rotational velocity of tool as compared to welding speed.

4. Tool probe geometry is very much responsible for deciding the weld quality..

5. The relationships between tool probe geometry and process parameters for FS welding of AA1100 aluminum alloy have been established. The response surface methodology was adopted to develop the regression models, which were checked for their adequacy using ANOVA test and found to be satisfactory.

\section{ACKNOWLEDGEMENTS}

The work has been supported by the Department of Scientific and Industrial Research (DSIR), India. The authors are grateful to DSIR for funding the work under TePP. The authors also thank Department of Ocean Engineering \& Naval Architecture, IIT Kharagpur for extending the experimental facilities at the welding laboratory.

\section{REFERENCES}

[1] Shinoda T (2001). Recent development of friction stir welding - newSolid-state joining technology. Int. J. Mater. Prod. Technol., 2: 453-460

[2] Ma ZY. Friction stir processing technology: a review. Metall Mater Trans A 2008;39A:642-58

[3] L. Dubourg, F. O. Gagnon, F. Nadeau, L. St-Georges, M. Jahazi. Process window optimization for FSW of thin and thick sheet Al alloys using statistical methods. In 6th Int. Symp. on FSW, 2006

[4] Mustafa Boz, Adem Kurt. The influence of stirrer geometry on bonding and mechanical properties in friction stir welding process. Materials and Design 25 (2004) 343-347
[5] Liu, F. C. and Ma, Z. Y. Influence of tool dimension and welding parameters on microstructure and mechanical properties of friction-stir-welded 6061-T651 aluminum alloy. Metall. Mater. Trans. A, Phys. Metall. Mater. Sci., 2008, 39, 2378-2388.

[6] Fujii, H., Cui, L., Maeda, M., and Nogi, K. Effect of tool shape on mechanical and microstructure of friction stir welded aluminum alloy. Mater. Sci.Engng A, Struct. Mater., Prop. Microstruct. Process., 2006, 419, 25-31.

[7] A. K. Lakshminarayanan and V. Balasubramanian. Process parameters optimization for friction stir welding of RDE-40 aluminium alloy using Taguchi technique. Trans. Nonferrous Met. Soc. China18:548-554,2008.

[8] G. Buffa, J. Hua, R. Shivpuri and L. Fratini. Design of the friction stir welding tool using the continuum based FEM model. Material Schience and Engineering A, 419:381-388, 2006.

[9] T. Nishihara. Development of simplified FSW tool. In $6^{\text {th }}$ International Symposium on FSW, 2006.

[10] G. Buffa, L. Fratini, S. Pasta and R. Shivpuri. On the thermo-mechanical loads and the resultant residual stresses in fiction stir processingoperations. InCIRP Annals - Manufacturing Technology 57:287-290, 2008.

[11] K. Elangovan and V. Balasubramanian, Influences of pin profile and rotational speed of the tool on the formation of friction stir processing zone in AA2219 aluminium alloy, Journal of Materials Science and Engineering A, 459 (2007) $7-18$.

[12] C. Blignault, D.G. Hattingh, and M.N. James. Optimizing Friction Stir Welding via Statistical Design of Tool Geometry and Process Parameters, Journal of Materials Engineering and Performance DOI: 10.1007/s11665-011-9984-2

[13] Minitab Inc, User manual of MINITAB statistical software, Release 13.31, State College,PA 16801 USA, 2000.

[14] S. Rajakumar and V. Balasubramanian. Multi-Response Optimization of Friction-Stir-Welded AA1100 Aluminum Alloy Joints, Journal of Materials Engineering and Performance Journal of Materials Engineering and Performance. DOI: $10.1007 / \mathrm{s} 11665-011-9979-\mathrm{z}$

[15] Mathews, P. G. Design and analysis of experimentswith MINITAB, 2004 (American Society for Quality Press, Milwaukee, Wisconsin).

[16] Montgomery, D. C. Design and analysis of experiments, 2001 (John Wiley \& Sons, Singapore).

[17] S. Vijayan, R. Raju and S.R. K. Rao. Multi objective Optimization of Friction Stir Welding Process Parameters on Aluminum Alloy AA 5083 Using Taguchi-Based Grey Relation Analysis, Mater. Manuf. Proc., 2010, 25, p 1206-1212

[18] H. K. Mohanty, M. M. Mahapatra,P. Kumar, P. Biswa and N. R. Mandal. Effect of tool shoulder and pin probe profiles on friction stirred aluminum welds - a comparative study, paper accepted for publication, journal of marine science application.

[19] P.A. Colegrove and H. R. Shercliff, 3-D CFD modeling of flow round a threaded FSW tool profile, Journal of material processing technology,104(2005), 320-327.

[20] H. N.B. Schmidt, and J. Hattel, "An analytical model for heat generation in FSW", Modeling and simulation in material science and engineering, 12(1) (2008), 143-157. 